\title{
Engineering geological studies for empirical design of tunnel 7 of Jakarta - Bandung high-speed railway, Indonesia
}

\author{
Riski Pramono ${ }^{1,2}$, I Gde Budi Indrawan ${ }^{1 *}$, Maulidya Indah Junica ${ }^{2}$ \\ ${ }^{1}$ Department of Geological Engineering, Faculty of Engineering, Universitas Gadjah Mada, Yogyakarta, Indonesia \\ ${ }^{2}$ The Ministry of Public Works and Housing, Jakarta, Indonesia
}

\begin{abstract}
The empirical design of tunnel 7 of the Jakarta-Bandung high-speed railway was based on the Basic Quality (BQ) system, which was the Chinese standard of rock mass classification. Due to the high uncertainty of a rock mass classification, comparative studies of rock mass quality and tunnel support systems based on other rock mass classifications are commonly required. The main objective of this research was to assess the rock mass quality and excavatability at the tunnel construction site and propose the tunnel support system based on three widely used methods, namely GSI, RMR, and Q-system. This study involved geological mapping, determination of surface and subsurface rock weathering, rock mass classification of drilling cores, and laboratory testing. The results show that the tunnel construction area consists of highly weathered volcanic and sedimentary rocks. The tunnel elevation consists of poor and extremely to very poor rock masses of sedimentary rocks. Hard digging is the optimum rock mass excavation method to use. Applications of rock bolt, wire mesh, and shotcrete are proposed for the tunnel support system.
\end{abstract}

\section{Introduction}

The Jakarta - Bandung high-speed railway Tunnel 7 Project is in West Bandung Regency, West Java Province (Fig. 1). The tunnel is a very environmentally friendly alternative compared to hill cutting. This tunnel is one of 13 tunnels traversed by the Jakarta - Bandung high-speed railway with a horseshoe-shaped and tunnel length of $1,225 \mathrm{~km}$, horizontal diameter of 15 meters, and a vertical diameter of 13 meters. The field study conducted including geological mapping, engineering geological mapping, mapping of surface and subsurface rock weathering, observations of core drilling results, and sampling for laboratory testing.

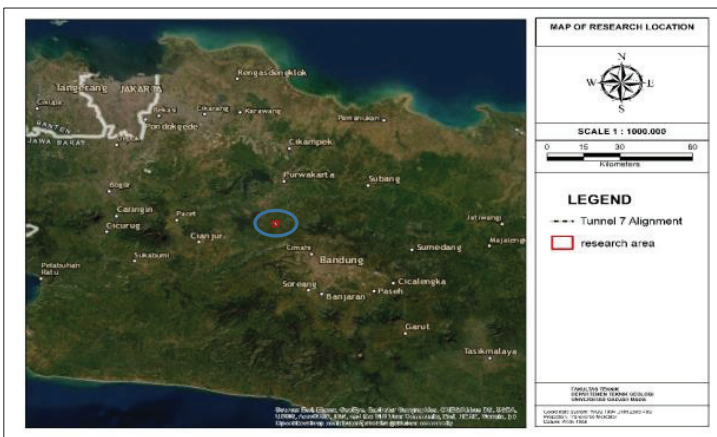

Fig. 1. Location of tunnel 7 Jakarta - Bandung high-speed railway
The planners designed this high-speed train tunnel based on the Professional Standard of The People's Republic of China "Code for Design on Tunnel of Railway." This guide uses the Basic Quality (BQ) rock mass classification issued by the Chinese government (Standard for Engineering Classification of Rock mass). Due to the high uncertainty in a rock mass classification, it is necessary to do a comparative analysis of rock mass quality using other widely used methods such as Rock Mass Rating (RMR), Q-system, and Geological Strength Index (GSI). The evaluation also needs to be done on the existing design as a comparison by using the empirical method of RMR and Q - System.

The empirical design method is based on rock mass classifications, which are widely utilized in rock engineering. Engineering rock mass classifications have improved their performance in recent years, and they are widely used in the design and construction of rock tunnels. The classification approach is sometimes the only practicable basis for designing complicated underground structures on many projects [1-2]. Rock mass classification systems are very useful tools for the preliminary design stage of a project when very little detailed information on rock mass is available. On the other hand, one or more rock mass classification methods may be used to create a picture of the composition and features of a rock mass to give initial support estimations and estimates of the rock mass strength and deformation properties [3].

Although the rock-mass rating (RMR) and tunneling quality index (Q) systems are used as empirical design tools in many rocks engineering

\footnotetext{
* Corresponding author: igbindrawan@ugm.ac.id
} 
projects, tunnel design is internationally accepted. These systems were created and upgraded, particularly for this purpose [4]. In this study, the determination of rock quality and support system was carried out empirically using the Rock Mass Rating (RMR), Q system (Q), and Geological Strength Index (GSI). The characteristics of the surrounding rock, tunnel diameter, and geometry are the basic input parameters for a safe tunnel design. The results of this study are expected to contribute to tunneling on weak rock masses, provide input for stakeholders, and help promote tunnel technology in the transportation sector in Indonesia.

\section{The research method}

The behavior of the rock surrounding a tunnel is critical to its stability. For an appropriate design that can be depended on, the various forms of behavior necessitate distinct evaluations or rock engineering methods. Selecting appropriate design tools based on geological and geotechnical conditions is critical. It should be highlighted that ground behavior cannot be defined. As a result, proper design work cannot be carried out without a comprehensive understanding of geology, ground conditions, and site-specific characteristics. The selection of appropriate design tools is mostly determined by the real ground behavior, such as an accepted standard or any other need [5].

The engineering studies conducted in this research involved surface geological and engineering geological mapping, evaluation of rock cores, and laboratory tests for assessment of rock quality and analyses of excavation methods and tunnel support systems. The surface geological and engineering geological mapping was carried out to assist the interpretation of subsurface geological and engineering geological conditions. The research flow chart is shown in Figure 3.

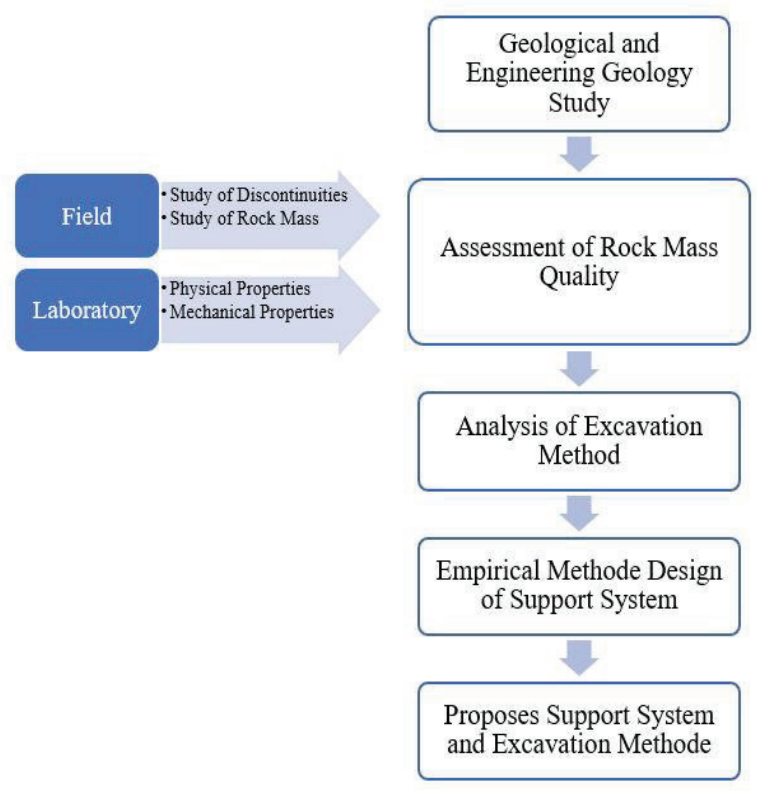

Fig. 2. Research flow diagram

\section{Geological conditions}

The Jakarta - Bandung high-speed railway Tunnel 7 is in the Bandung Zone based on the grouping that has been written by Van Bemmelen [6]. This zone has three lithological formations consisting of Old Volcanoes Results (Qob), Cantayan Formation (Mtts), and the Jatiluhur Formation (Mdm) based on the regional geological map sheet of Cianjur [7], as shown in Fig. 3.

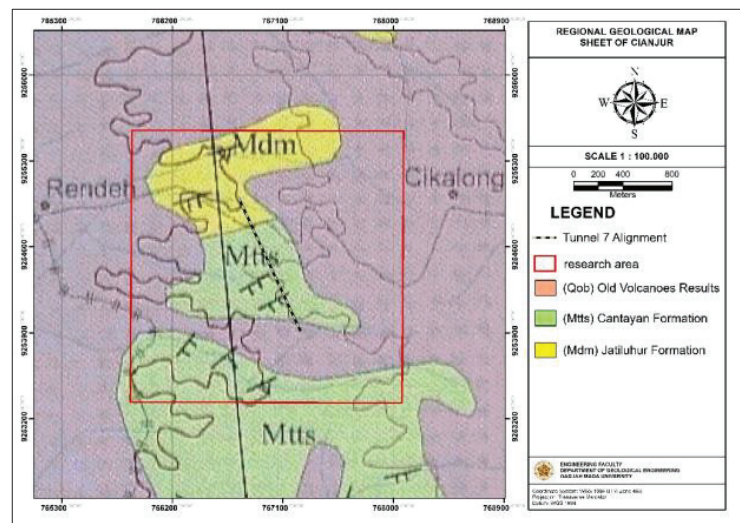

Fig. 3. Regional geological map of the research area

Results of surface geological mapping showed that the research area consists of volcanic breccia and laharic breccia of the Old Volcanoes (Qob) Formation, siltstone of the Cantayan Formation (Mtts), and sandstone and claystone bedding units of the Jatiluhur formation (Mdm), as shown in Fig. 4.

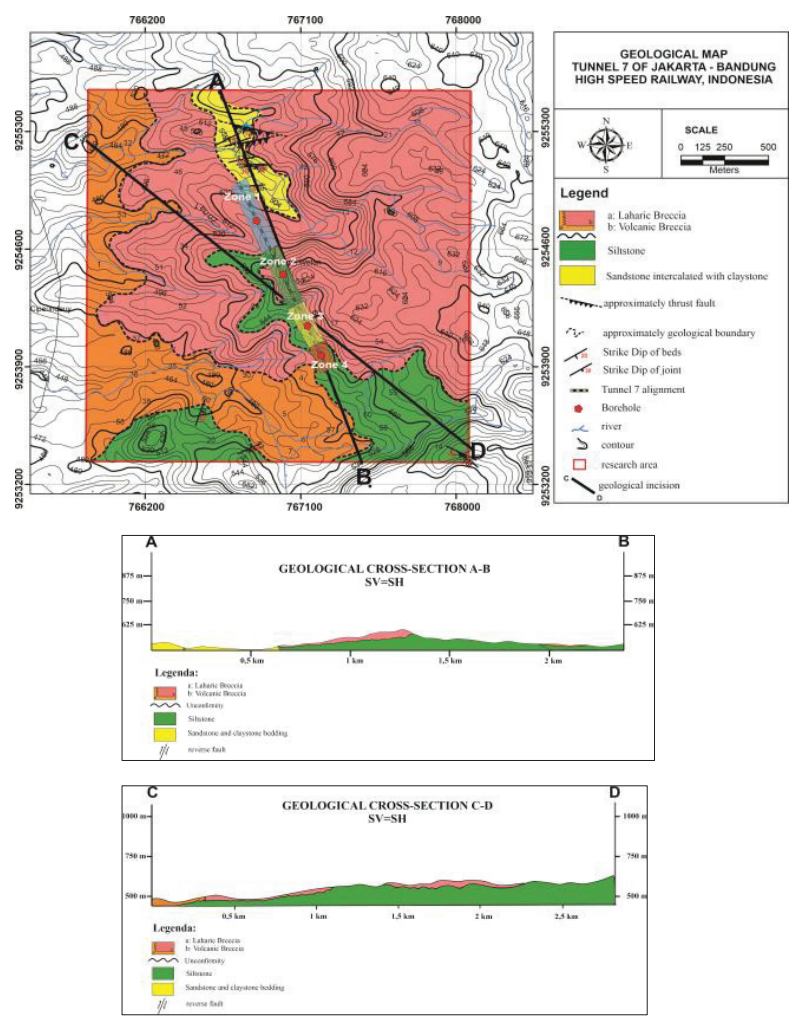

Fig. 4. Geological map of the research area 


\section{Engineering geological conditions}

The geological engineering studies include both field and laboratory studies. The field studies consist of field observation, discontinuity surveys, and boreholes. Laboratory tests were conducted on samples collected from the field and the boreholes (Fig. 5.) The quantitative description of rock discontinuities, such as roughness, orientation, persistence, filling, and aperture, was determined in the field using the ISRMrecommended methods.

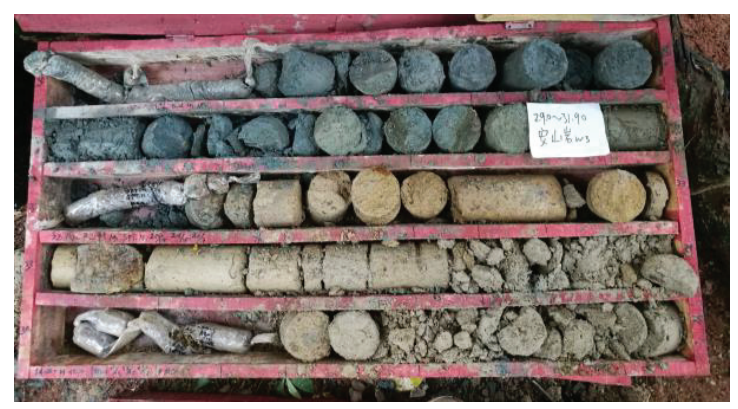

Fig. 5. Core drill zone 1 at 30-35 m depth (documentation of PT. KCIC)

The tectonic history of a rock mass has a significant impact on its quality. Radbruch-Hall (1975) evaluated the geology and tectonism (past and present) of each of California's physiographic provinces and their impact on slope stability and engineering practice. Folding and fracture were thought to make the granite mass more prone to weathering, erosion, and landslides. Current tectonic activity in California generates large earthquakes and triggers slope collapses [8]. Massironi et al. (2003) revealed that the tectonic history of the eastern Italian Alps resulted in ductile and brittle deformation structures that govern the various failure mechanisms functioning at three sites within a $10 \mathrm{~km}$ radius. The direction of the discontinuity and the position of the slope failure concerning the faults, folds, and orientation provided planes of weakness that favored lateral spreading, sackung development, or rockfall [9].

Engineering geological conditions describe the geological conditions, weathering rate, and rock quality. The geological surface engineering study site is divided into four units of engineering geology, namely highly weathered laharic breccias, highly weathered volcanic breccias, highly weathered siltstone, and highly weathered sandstone intercalated with claystone as shown in figure 6. Laboratory testing is carried out directly from drilling results according to the lithology and level of rock weathering. Tests were conducted on soil and rock index properties, shear strength, rock UCS, and triaxial rock strength. This testing is conducted to determine the parameters required in establishing the excavation method and tunnel stability. All laboratory tests were carried out in compliance with the ISRM recommended procedures.

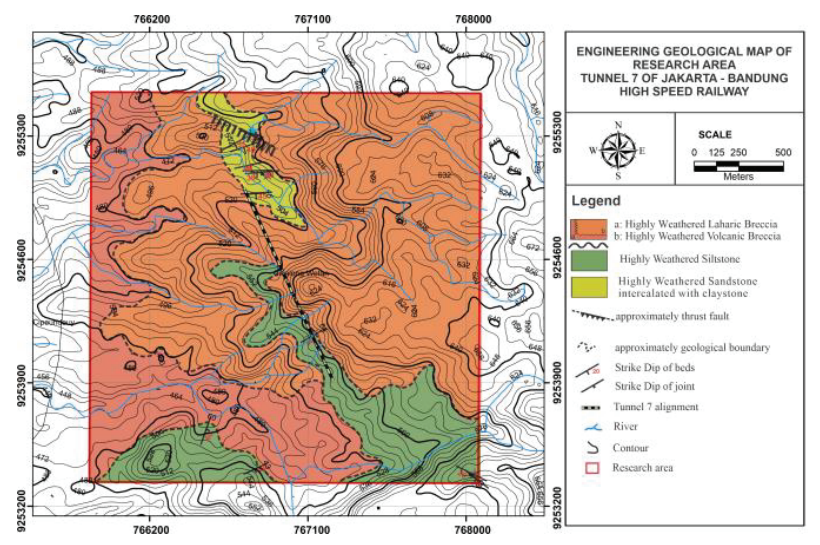

Fig. 6. Engineering geological map of the research area

\section{Rock mass quality}

\subsection{Geological strength index (GSI)}

According to Hoek and Marinos [10], the Geological Strength Index (GSI) can be determined directly from the outcrop covering two main parameters, namely the condition of the structure (structure) and the condition of its surface (surface condition). In this study, the GSI value was determined based on subsurface data from the results of drilling carried out at the tunnel location. Calculation of subsurface GSI, according to Hoek et al. [11], can be determined using the relationship between Joint Condition [12] and the value of Rock quality designation (RQD) [13]. The subsurface GSI value can be calculated using the following equation:

$$
G S I=1,5 \text { Jond }_{89}+R Q D / 2
$$

\subsection{Rock mass rating (RMR)}

According to Bieniawski [12], rock mass classification from the Rock Mass Rating (RMR) method uses six parameters obtained from field measurements or observations from drill data. The six parameters used in rock mass classification from the RMR) method are as follows: Uniaxial Compressive Strength (UCS) intact rock material, rock quality designation (RQD), discontinuity spacing, discontinuity conditions, groundwater condition, and discontinuity orientation.

The Rock Mass Rating (RMR) value can be found by calculating the values of all these parameters. The RMR classification can determine the excavation method and tunnel support systems according to the rock mass class. This paper calculates the RMR value to determine the support system. The RMR value is determined using the Hoek and Brown [14] correlation formula in equation 3 .

\subsection{Q-System}

According to Barton [15], the Tunnelling Quality Index (Q) is a system that considers six parameters: RQD, amount of stock, roughness, change in stock, water 
condition of the stock, and pressure factor. The Q-value can be calculated using the following equation [15]:

$$
Q=\left(\frac{R Q D}{J n}\right)\left(\frac{J r}{J a}\right)\left(\frac{J w}{S R F}\right)
$$

This paper calculates the $\mathrm{Q}$ value to determine the support system based on the $\mathrm{Q}$ value. The $\mathrm{Q}$ value is determined using the Bieniawski [12] correlation formula in equation 4 .

\subsection{Correlation of RMR and GSI}

The rock mass classification based on GSI is a development of RMR. Hoek and Brown [14] explain that the RMR classification based on Bieniawski [12] can estimate the GSI value as in the 1976 version. The rating of the groundwater under dry conditions is 15 , and the orientation of the discontinuity is 0 in this case. The minimum value for the classification of the rock mass of RMR is based on Bieniawski [12] is 23. The final weight of this rock mass classification is called $\mathrm{RMR}_{89}$ Furthermore, it can be used to estimate the GSI value. If the value is $\mathrm{GSI} \geq 18$ or $\mathrm{RMR} \geq 23$, then:

$$
\mathrm{RMR}_{89}=\mathrm{GSI}+5
$$

\subsection{Correlation of RMR and Q-System}

Bieniawski [12] has provided various kinds of correlations between RMR and other parameters, but the most applicable correlation is the correlation between RMR and Q value, with the following formula:

$$
Q=10^{\frac{R M R-50}{15}}
$$

\subsection{Assessment of rock mass quality}

Determination of the quality of the subsurface rock mass in this study was obtained from the borehole results. The quality of the rock mass is obtained from the 4-point borehole data, with the following results:

Table 1. Summary assessment of rock mass quality

\begin{tabular}{|c|c|c|c|c|c|c|}
\hline Zone & $\begin{array}{c}\text { Weathering } \\
\text { rate }\end{array}$ & GSI & RMR & $\begin{array}{c}\text { Rock } \\
\text { Mass } \\
\text { Quality }\end{array}$ & Q & $\begin{array}{c}\text { Rock } \\
\text { Mass } \\
\text { Quality }\end{array}$ \\
\hline 1 & $\begin{array}{c}\text { Highly } \\
\text { weathered }\end{array}$ & 22 & 27 & Poor & 0.029 & $\begin{array}{c}\text { Extremely } \\
\text { poor }\end{array}$ \\
\hline 2 & $\begin{array}{c}\text { Highly } \\
\text { weathered }\end{array}$ & 31 & 36 & Poor & 0.117 & Very poor \\
\hline 3 & $\begin{array}{c}\text { Highly } \\
\text { weathered }\end{array}$ & 20 & 25 & Poor & 0.022 & $\begin{array}{c}\text { Extremely } \\
\text { poor }\end{array}$ \\
\hline 4 & $\begin{array}{c}\text { Highly } \\
\text { weathered }\end{array}$ & 18 & 23 & Poor & 0.016 & $\begin{array}{c}\text { Extremely } \\
\text { poor }\end{array}$ \\
\hline
\end{tabular}

\section{Analysis of excavation method}

The rock excavation method is determined by the type of rock material, especially its geotechnical properties. Discontinuity planes and intact rock are examples of this important property. Other factors, such as fractures, the contents of the fractures, and the strength of the discontinuity plane are other important.

Pettifer and Fookes [16] proposed a rock excavation method using blasting, ripping, and digging. The excavation method is recommended together with the equipment used. The excavation method recommendation is based on the value of the discontinuity plane spacing index (If) and the point load index (Is (50)). The value of JV is obtained from the sum of the frequency of fractures or fractures that have the same direction pattern called a joint set. The calculation formula that can be used is the following equation:

$$
\begin{gathered}
I f=\frac{3}{J v} \\
J v=\frac{1}{S 1}+\frac{1}{S 2}+\frac{1}{S 3}
\end{gathered}
$$

Table 2. If and Is50 load values to be plotted in the graph of Pettifer and Fookers [16]

\begin{tabular}{|ll|c|c|c|}
\hline \multicolumn{2}{|c|}{ Lithology } & $\begin{array}{c}\text { Rock Mass } \\
\text { Classification }\end{array}$ & If & $\begin{array}{c}\text { Is50 } \\
\text { (Mpa) }\end{array}$ \\
\hline Laharic breccia & \multirow{2}{*}{ Poor rock } & 1.13 & 0.17 \\
\hline Volcanic breccia & \multirow{2}{*}{ Claystone } & Poor rock & 1.01 & 0.17 \\
\hline Siltstone & Poor rock & 0.68 & 0.04 \\
\hline Sandstone & Poor rock & 0.76 & 0.04 \\
\hline
\end{tabular}

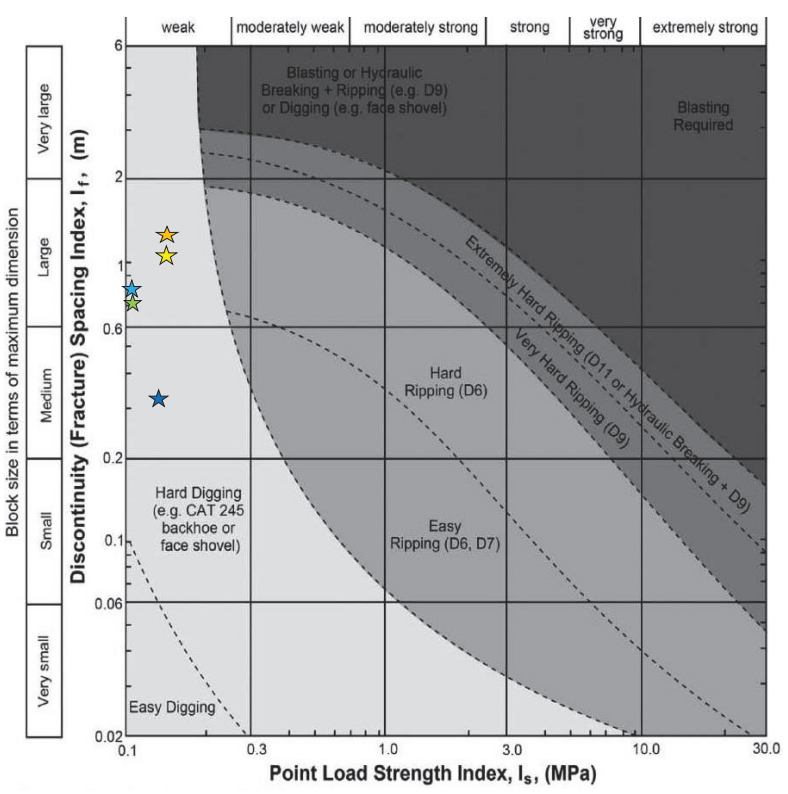

Fig. 7. The plot of rock excavation method.

Based on the plotting results in fig. 7, most of them indicate that the most suitable excavation method is hard digging. 


\section{Empirical design of support system}

Based on RMR classification systems, the necessary support systems for the zone along the tunnel route are presented in Table 3.

Table 3. The recommended supports are based on the RMR.

\begin{tabular}{|c|c|c|c|}
\hline Zone & RMR & $\begin{array}{l}\text { Rock Mass } \\
\text { Quality }\end{array}$ & $\begin{array}{c}\text { Support System Base on } \\
\text { Q-System }\end{array}$ \\
\hline \multirow{3}{*}{ Zone 1} & \multirow{3}{*}{27} & \multirow{3}{*}{ Poor } & $\begin{array}{l}\text { Rockbolt: } \mathrm{L}=5 \mathrm{~m} \text { with } \\
\text { spaced }=1.5 \mathrm{~m} \text { in crown } \\
\text { and wall }\end{array}$ \\
\hline & & & $\begin{array}{l}\text { Shotcretet: } \mathrm{t}=150 \mathrm{~mm} \\
(\text { crown }) \mathrm{t}=100 \mathrm{~mm} \text { (wall) }\end{array}$ \\
\hline & & & $\begin{array}{l}\text { Wiremesh: in crown and } \\
\text { wall }\end{array}$ \\
\hline \multirow{3}{*}{ Zone 2} & \multirow{3}{*}{36} & \multirow{3}{*}{ Poor } & $\begin{array}{l}\text { Rockbolt: } \mathrm{L}=5 \mathrm{~m} \text { with } \\
\text { spaced }=1.5 \mathrm{~m} \text { in crown } \\
\text { and wall }\end{array}$ \\
\hline & & & $\begin{array}{l}\text { Shotcretet: } \mathrm{t}=150 \mathrm{~mm} \\
(\text { crown) } \mathrm{t}=100 \mathrm{~mm} \text { (wall) }\end{array}$ \\
\hline & & & $\begin{array}{l}\text { Wiremesh: in crown and } \\
\text { wall }\end{array}$ \\
\hline \multirow{3}{*}{ Zone 3} & \multirow{3}{*}{25} & \multirow{3}{*}{ Poor } & $\begin{array}{l}\text { Rockbolt: } \mathrm{L}=5 \mathrm{~m} \text { with } \\
\text { spaced }=1.5 \mathrm{~m} \text { in crown } \\
\text { and wall }\end{array}$ \\
\hline & & & $\begin{array}{l}\text { Shotcretet: } \mathrm{t}=150 \mathrm{~mm} \\
(\text { crown) } \mathrm{t}=100 \mathrm{~mm} \text { (wall) }\end{array}$ \\
\hline & & & $\begin{array}{l}\text { Wiremesh: in crown and } \\
\text { wall }\end{array}$ \\
\hline \multirow{3}{*}{ Zone 4} & \multirow{3}{*}{23} & \multirow{3}{*}{ Poor } & $\begin{array}{l}\text { Rockbolt: } \mathrm{L}=5 \mathrm{~m} \text { with } \\
\text { spaced }=1.5 \mathrm{~m} \text { in crown } \\
\text { and wall }\end{array}$ \\
\hline & & & $\begin{array}{l}\text { Shotcretet: } \mathrm{t}=150 \mathrm{~mm} \\
(\text { crown) } \mathrm{t}=100 \mathrm{~mm} \text { (wall) }\end{array}$ \\
\hline & & & $\begin{array}{l}\text { Wiremesh: in crown and } \\
\text { wall }\end{array}$ \\
\hline
\end{tabular}

The excavation and support system for all zone which has rock mass classification RMR is poor rock. So, the recommended excavation is gradual with a heading and benching system. The excavation and support systems for all zones based on the RMR rock mass classification are rock poor. Based on the quality of the rock mass, it is recommended that excavation be carried out in stages with a heading and benching system. Install completely grouted rock bolts with a length of 5 meters and spaced 1.5 meters at the crown and walls in a systematic way. Install wire mesh on the crown and wall, then shotcrete thickness of $150 \mathrm{~mm}$ on the crown and $100 \mathrm{~mm}$ on the wall. The installation of steel sets (steel ribs) with a 1.5 meter spacing was then combined.

Determination of the tunnel support system based on the Q system classification [15] is determined based on the $\mathrm{Q}$ value, the tunnel height or span, and the Excavation Support Ratio (ESR) value. The height of the tunnel used in this study is 13 meters, while the ESR value is 1 (railway tunnel) so that the ratio between the height and the ESR is 13. The support system at four zones in the study area is as shown in Fig. 8.

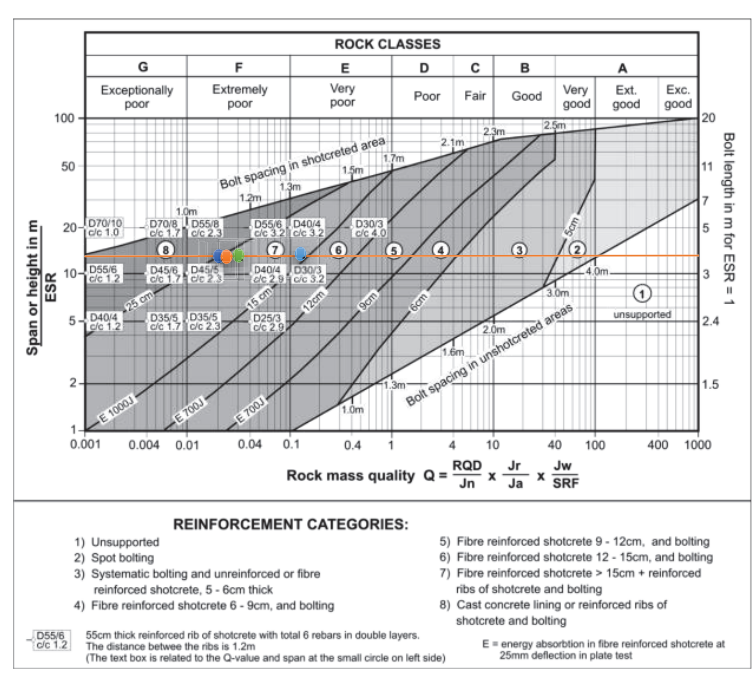

Fig. 8. The plot point for determining the support system is based on the Q system.

Based on $Q$ value classification systems, the support systems for the zone along the tunnel route are presented in Table 4.

Table 4. The recommended supports are based on the Q System

\begin{tabular}{|c|c|c|c|}
\hline Zone & $\begin{array}{c}\text { Q } \\
\text { Value }\end{array}$ & $\begin{array}{l}\text { Rock } \\
\text { Mass } \\
\text { Quality }\end{array}$ & $\begin{array}{c}\text { Support System Base on } \\
\text { Q-System }\end{array}$ \\
\hline \multirow[t]{2}{*}{ Zone 1} & \multirow[t]{2}{*}{0.03} & \multirow{2}{*}{$\begin{array}{l}\text { Extremely } \\
\text { Poor }\end{array}$} & $\begin{array}{l}\text { Rockbolt: } \mathrm{L}=3.8 \mathrm{~m} \text { with } \\
\text { spaced }=1.2 \mathrm{~m} \text { in crown } \\
\text { and wall }\end{array}$ \\
\hline & & & $\begin{array}{l}\text { Shotcretet: } \mathrm{t}=240 \mathrm{~mm} \\
\text { (crown and wall) }\end{array}$ \\
\hline \multirow[t]{2}{*}{ Zone 2} & \multirow[t]{2}{*}{0.12} & \multirow[t]{2}{*}{ Very Poor } & $\begin{array}{l}\text { Rockbolt: } \mathrm{L}=3.8 \mathrm{~m} \text { with } \\
\text { spaced }=1.3 \mathrm{~m} \text { in crown } \\
\text { and wall }\end{array}$ \\
\hline & & & $\begin{array}{l}\text { Shotcretet: } \mathrm{t}=230 \mathrm{~mm} \\
\text { (crown and wall) }\end{array}$ \\
\hline \multirow[t]{2}{*}{ Zone 3} & \multirow[t]{2}{*}{0.02} & \multirow{2}{*}{$\begin{array}{l}\text { Extremely } \\
\text { Poor }\end{array}$} & $\begin{array}{l}\text { Rockbolt: } \mathrm{L}=3.8 \mathrm{~m} \text { with } \\
\text { spaced }=1.2 \mathrm{~m} \text { in crown } \\
\text { and wall }\end{array}$ \\
\hline & & & $\begin{array}{l}\text { Shotcretet: } \mathrm{t}=240 \mathrm{~mm} \\
\text { (crown and wall) }\end{array}$ \\
\hline \multirow[t]{2}{*}{ Zone 4} & \multirow[t]{2}{*}{0.02} & \multirow{2}{*}{$\begin{array}{l}\text { Extremely } \\
\text { Poor }\end{array}$} & $\begin{array}{l}\text { Rockbolt: } \mathrm{L}=3.8 \mathrm{~m} \text { with } \\
\text { spaced }=1.2 \mathrm{~m} \text { in crown } \\
\text { and wall }\end{array}$ \\
\hline & & & $\begin{array}{l}\text { Shotcretet: } \mathrm{t}=240 \mathrm{~mm} \\
\text { (crown and wall) }\end{array}$ \\
\hline
\end{tabular}

\section{Conclusions and discussion}

This study involved geological mapping, determination of surface and subsurface rock weathering, rock mass classification of drilling cores, and laboratory testing. The study area consists of highly weathered laharic breccias, highly weathered volcanic breccias, highly weathered siltstone, and highly weathered sandstone intercalated with claystone. The tunnel elevation consists of poor rock masses based on the RMR and very poor to extremely poor rock masses according to Qsystem. 
The suggested rock mass excavation method is hard digging. The recommended supports are based on the RMR applied rock bolt length 5 meters with spaced 1.5 meters in crown and wall, wire mesh in crown and wall, and shotcrete thickness of $150 \mathrm{~mm}$ on the crown and 100 $\mathrm{mm}$ on the wall. The recommended supports are based on the Q-system applied rock bolt length 3.8 meters with spaced $1.2-1.3$ meters in crown and wall, and shotcrete thickness of $230-240 \mathrm{~mm}$ on the crown and wall. Designing a tunnel with an empirical approach is very helpful in preliminary design. The further numerical study is required to determine the most optimum tunnel support design by comparing the tunnel support design determined by the Chinese standard of rock mass classification and that determined by the rock mass classifications used in this study.

The authors would like to thank PT. Kereta Cepat Indonesia China (KCIC), High-Speed Railway Consortium (HSRCC), China Railway Design Corporation (CRDC), and China Railway Group Limited (CREC) for the permission to conduct this research and supplying site investigation data. The first author would also like to thank The Ministry of Public Works and Housing of Indonesia for providing financial support.

\section{References}

1. R.K. Goel, B. Singh, Engineering Rock Mass Classification: Tunnelling, Foundations, and Landslides. Elsevier Science (2011)

2. FHWA. Technical Manual for Design and Construction of Road Tunnels Federal Highway Administration. US Department of Transportation: Washington DC (2009)

3. E. Hoek, Practical Rock Engineering: RocScience. (2007)

4. ISRM, Suggested Methods for The Quantitative Description of Discontinuities in Rock Masses: International Society for Rock Mechanics. International Journal of Rock Mechanics and Mining Science \& Geomechanics Abstracts, 15: 319-368 (1978)

5. A. Palmstrom, H. Stille, Ground behavior and rock engineering tools for underground excavations. Tunneling Underground Space Technol, 22, 363376 (2007)

6. V. Bemmelen, The Geology of Indonesia Vol. IA General Geology of Indonesia and Adjacent Archipelagoes, The Hague: Government Printing Office (1949)

7. Sudjatmiko, Peta Geologi Lembar Cianjur, Jawa. Bandung: Pusat Penelitian dan Pengembangan Geologi (2013)

8. D.H. Radbruch-Hall, Tectonic Activity in California, and its Relation to Engineering Geology. In: Geologica Carpathica XXVI, Bratislava, pp. 161-1 69 (1975)

9. M. Massironi, A. Bitacchi, G.V. Dal Piaz, B. Monopoli, A. Schiavo, Structural Control on MassMovement Evolution: A Case Study from the Vizze
Valley, Italian Eastern Alps, Eclogae Geologicae Helvetiae, 96: 85-98. (2003)

10. P. Marinos, E. Hoek, GSI: a geologically friendly tool for rock mass strength estimation, ISRM international symposium, International Society for Rock Mechanics and Rock Engineering (2000)

11. E. Hoek, T. G. Carter, M. S. Diederichs. Quantification of the geological strength index chart. 47th US rock mechanics/geomechanics symposium, American Rock Mechanics Association (2013)

12. Z. T. Bieniawski, Engineering rock mass classifications: a complete manual for engineers and geologists in mining, civil, and petroleum engineering, John Wiley \& Sons (1989)

13. D.U. Deere, Technical description of rock cores for engineering purposes, Felsmechanik und Ingenieurgeologie (Rock Mechanics and Engineering Geology), 1(1): 16-22, (1963)

14. E. Hoek, E.T. Brown, Practical estimates of rock mass strength, international journal of rock mechanics and mining sciences, 34(8): 1165-1186 (1997)

15. N. Barton, R. Lien, J. Lunde, Engineering Classification of Rock Masses for the Design of Tunnel Support, Oslo: Norwegian Geotechnical Institute Publication 106 (1974)

16. G.S. Pettifer, P.G. Fookes, A Revision of The Graphical Method for Assessing the Excavatability of Rock, Quarterly Journal of Engineering Geology 27 (1994) 